\title{
Research on Initial Trust Model of Mobile Banking Users
}

\author{
Baolin Sun ${ }^{1}$, Chaohao Sun ${ }^{2}$, Chang Liu ${ }^{1}$, Chao Gui ${ }^{1}$ \\ ${ }^{1}$ School of Information Engineering, Hubei University of Economics, Wuhan 430205, China, \\ Wuhan 430205, China \\ E-mail:blsun@163.com,liu.chang@vip.126.com,gui_chao@126.com \\ ${ }^{2}$ China Huarong Financial Leasing Co., LTD, \\ Hangzhou 310007, China \\ E-mail: skypedestrian@163.com
}

Received 18 February 2017

Accepted 28 February 2017

\begin{abstract}
The trust mechanism and trust model of mobile banking is especially urgent because of its high cognitive risk and poor experience. This article studies several key factors that affect the trust mechanism of mobile banking, such as structure assurance, ubiquity, information quality, initial trust, perceived ease of use and experience. The results show that structure assurance is a most important factor influencing trust tendencies, and ubiquity, information quality, perceived satisfaction and perceived ease of use are some other key factors that affect initial trust and experience. The initial trust directly affects the users' sense of experience of mobile banking and decides the tendency of trust, which affects the actual use. Therefore, the mobile phone banks need to pay more attention to the initial sense of trust and experience to promote user acceptance and trust mobile banking services.
\end{abstract}

Keywords: mobile banking, structure assurance, initial trust, sense of experience, trust tendencies.

\section{Introduction}

Mobile banking, also known as Mobile Bank, is a typical application in the mobile financial field. It refers to the integration of electronic money and mobile communication services through multi-industry and multi-platform cooperation between mobile telecom carriers and banking institutions. With the help of the fourth generation mobile communication technology (4G) for mobile phone users, it provided a new mode of financial payment services. Mobile banking can provide bank account information inquiries, account transfers, bank and securities transfer, securities trading, payment, financial information, and many other financial services.

The main advantage of mobile banking is that it's "everywhere" as compared with internet banking (usually refers to the PC side), because the mobile banking service is mainly based on the binding of bank card and credit card on the basis of mobile phone number to complete the financial payment service. In other words, with the help of mobile communication platform, mobile banking payment system and smart phone, smartphone users can accomplish the financial payment service at any time and any place, thus promoting the use of mobile banking for smartphone users. However, smart phones also have limitations, such as the small screen, inconvenient input and slow processing speed, as well as the instability of the mobile operating system, mobile communication security loopholes, distrust between smart phone users and banks. In this distributed, dynamic and mobile financial application system is composed of multiple platforms, multiple service organizations and multiple technical services, the lack of a restrictive mechanism for financial institutions, mobile operators and smartphone users, and the lack of confidence among entities, the 
large number of fraudulent acts and untrusted services events, result in financial transactions among financial institutions, mobile operators and mobile phone users which those entities behaviors can be presented as dynamic, security and uncertainty, restricting the smart phone users on mobile banking acceptance and use. In the mobile communication environment, mobile phone user's trust, banking services, 4G communication technology play an important role in the success of mobile banking. Therefore, the establishment of an effective trust mechanism is very helpful to assess the conduct of the credibility of the mobile banking financial security and credibility of great significance among financial institutions, mobile operators and smart phone users.

According to "China's e-banking survey in 2015", it showed that in 2015, the proportion of individual online banking users was $35.6 \%$, increased by $10 \%$ compared to 2014; personal mobile banking users ratio was $32 \%$ which increased by $14.5 \%$; the proportion of mobile phone users was $88 \%$, increasing by $5 \%$; the proportion of mobile banking users was $58 \%$, decreased by $18 \%$. According to the theory of innovative diffusion, mobile banking has crossed the 'take-off point"'. The report also pointed out that the ratio of use of mobile phone APP orders, WeChat, mobile payment Alipay and other third-party payment is $31 \%$, QR code scanning payment is $24 \%$, smartphone wallet payment is $10 \%$, and mobile phone acoustic payment is $6 \%$. The trend of mobile payment business is very obvious, once mobile phone users start using mobile banking, they will quickly transfer their bank account information inquiries, micropayment services, mobile securities, counter the business to the mobile phone bank, and gradually fall into a habit of using mobile banking.

\section{Mobile banking initial trust mechanism and model of the status quo}

In recent years, many foreign and domestic scholars have used different theories and methods to carry out effective research on trust-related issues, and put forward many trust evaluation models, social norms and other important trust structures. As for the extension of mobile banking, in previous research on the consumer demographic characteristics, we identified the role of mobile banking risk in ways of using mobile banking with or without trust mechanism. Tian Junfeng (2011) studied key mechanisms of the trust model, methods and existing problems such as a review of the trust model for further study to provide a good reference and guidance. The results of Shaikh (2012) research showed that the technical structure of mobile banking, mobile communication security and ease of use, perceived usefulness, and quality of service on the use of mobile banking have an important role. Fang Zeyin (2012) analyzed the security factors of existing mobile banking security and its shortcomings, and put forward secure solutions for mobile banking security encryption card, thus establishing the theoretical foundation of financial security, business development, and large-scale application for mobile banking.

David Carf (2012), an American scholar, studied the operational risks of mobile banking, and put forward major operational risks: mobile phone operation risk, information asymmetry risk, credit risk, and mobility risk. Through empirical research, Afshan (2016) analyzed the security structure of mobile banking, the quality of mobile communications technology, making a significant contribution on the use of mobile banking. Meanwhile, structural assurance is an important guarantee for mobile phone users to the initial trust of mobile banking, and the convenience of operation system will be more conducive to users of mobile banking. Jiabao Lin (2011) carried out research on mobile trust for mobile securities that impacts mobile phone investors to adopt securities trading activities, and pointed out that the initial trust of mobile securities is a trading determinant of mobile security. Lin (2011) studied the trust and payment process of mobile banking with the theory of diffusion of innovation and trust theory. The results show that the relative advantage and perceived ability have a strong influence on mobile phone users' attitude towards using mobile banking. In addition, Shuihong Yao (2013) studied the relationship between the service quality of mobile banking and the continuous trust of customers, and established trust model between mobile banking service quality and customer continuous trust. The empirical test shows that the service quality of mobile banking to mobile banking Customer's ongoing trust has an important role.

The study of Zhou (2012) points out that the impact of trust on mobile banking users' behavior is significant. In our previous study (2016), we analyzed several main factors that affect the quality of communication, selfefficacy, perceived risk, ubiquity, perceived satisfaction, structural assurance, initial trust, experience, and trust 
tendencies of mobile banking, This paper presents a multi-dimensional trust mobile banking risk evaluation index system based on mobile banking customer direct trust, mobile banking customer trust decay, mobile banking financial business trust, and mobile banking customer final trust evaluation.

\section{Mobile banking multi-dimensional trust relationship structure and risk evaluation model}

\subsection{Mobile banking experience in payment}

Mobile banking payment experience is defined as a sense of the overall, which is the overall feeling when they use the mobile phone operators to pay for mobile banking. The mobile payment process is characterized by: (1) operations on the smart phone according to information related on the screen; (2) inner feelings and self-awareness of the operation; (3) operational awareness of the subjective initiative in payment; (4) enhanced awareness of the operation of the mobile payment system. The payment process also reflects the degree of responsiveness and the associated balance between mobile phone users and the financial system.

\subsection{The relationship between mobile banking multi-dimensional trust structures}

Fig. 1 shows the structure of mobile banking multidimensional trust relationship. The main influencing factors are structure assurance, ubiquity, information quality, perceived satisfaction and perceived ease of use, and the influence of initial trust and experience. Smartphone users' experience perception can determine the tendency of trust in a better way.

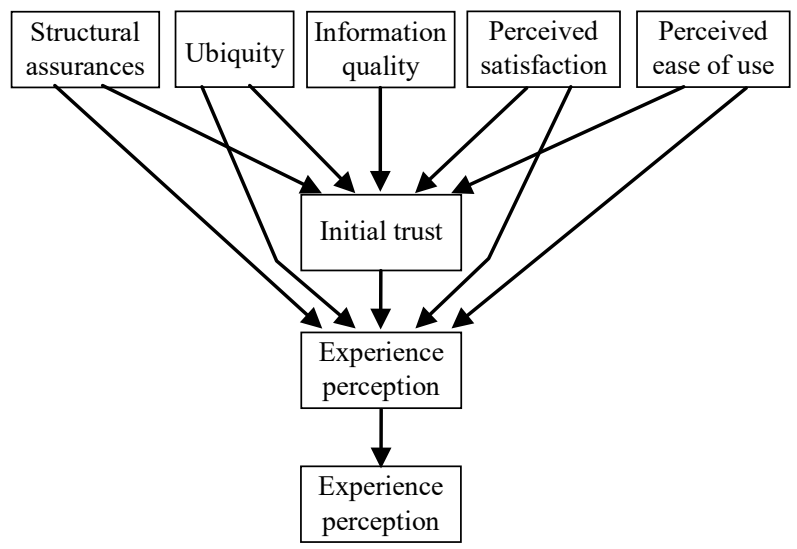

Fig. 1. Mobile banking multidimensional trust relationship structure.
As an important and fundamental trust mechanism, the structure assurance can effectively establish the trust of the smart phone users for the financial payment and reduce the perceived risk of their online transactions. Structure assurance means sufficient technical and legal structure to ensure that the mobile banking payment architecture and payment security structure in order to establish initial trust with the mobile phone users. Structural security can also enable mobile phone users have better experience with mobile banking.

Ubiquity means that in the mobile terminal and the Internet, smartphone users can access financial system at anytime, anywhere, so that the financial system can be presented to smart phone users services everywhere.

Information quality refers to the quality of the technology, skills and transmission data required by the mobile operators and the banking service providers to fulfill their payment processes. Quality of information reflects the technical assurance provided by service providers, promise, and no deceit to users. The quality of information affects the initial trust and experience of smartphone users.

In the mobile banking environment, user perceived satisfaction refers to the behavior or willingness of mobile phone users to participate in the mobile banking process and share the mobile banking. Perceived satisfaction can improve the initial trust and experience.

Perceived ease of use mainly reflects the difficulty of smart phone users to use mobile banking to pay in the process. Because of some limitations of smart phones, such as mobile phone small screen, multi-screen inconvenient operation and input, smartphone users cannot operate so easy as when they does with computer. Perceived ease of use is conducive to improving the trust of mobile phone users and the use of mobile banking experience.

Trust reflects the relationship between mobile banking service providers and smartphone users, and common interests. Initial trust also affects smartphone users' experience. Trust provides a guarantee that mobile banking users buy mobile banking services provided, they also feel that the use of mobile banking is guaranteed and will have a better sense of experience.

Initial trust and experience will affect the using willingness of mobile banking users. In addition, initial trust mitigates some uncertainties and risks in the process of using the mobile banking payment and promotes the payment behavior of mobile banking 
users, making the good sense of experience reach its culmination, and benefiting mobile phone banking user's in trust tendencies.

\subsection{Financial risk assessment model of multidimensional trust mobile banking}

1. Mobile banking customer direct trust model: In order to improve the accuracy of the trust evaluation index and dynamic adaptability, so a period of time the business is divided into several business, set $t_{1}, t_{2}, \ldots, t_{n}$. In the nth business time, we assume that the number of times between the mobile banking service $i$ and the mobile banking service $j$ is $m$, then the direct trust degree $D_{n}(i, j)$ can be expressed as

$$
D_{n}(i, j)=\left\{\begin{array}{l}
\frac{\sum_{k=1}^{m} f(i, j)}{m}, \quad m \neq 0 ; \\
0, \quad m=0 .
\end{array}\right.
$$

2. Mobile banking financial trust model: we use $P T(i, j)$ as the trust that mobile banking services $i$ to mobile banking financial services $j$, and consider the nth financial payment business factors, then $P T(i, j)$ can be calculated as

$$
P T_{n}(i, j)=\alpha D_{n}(i, j)+(1-\alpha) R_{n}(i, j), \alpha \in[0,1]
$$

Among them, $\alpha(0<\alpha<1)$ is the trust adjustment factor, which is related to the degree of importance of direct trust and indirect trust.

\section{Empirical research and data analysis of mobile banking}

\subsection{Collection of Samples}

In this paper, 10 senior college students are invited to collect and distribute questionnaires to citizens who own smartphones. A total of 500 questionnaires were distributed, then 452 questionnaires were retrieved, and 28 filled-out cases were removed from the 15 offices of five banks and the six operating rooms of the three telecom-operators in Wuhan Optics Valley. Except for invalid and incomplete questionnaires, a total of 424 valid ones were collected. Of these valid questionnaires, 45 were bank employees, 134 were employees, 127 were employees of institutions (including schools), and 86 were of other occupations. The distribution of the sample characteristics is shown in Table 1.

\begin{tabular}{|c|c|c|c|}
\hline $\begin{array}{l}\text { Personnel } \\
\text { Structure }\end{array}$ & $\begin{array}{c}\text { Option } \\
\text { Structure }\end{array}$ & $\begin{array}{c}\text { Quantity } \\
\text { Proportion }\end{array}$ & $\begin{array}{c}\text { Percentage } \\
(\%)\end{array}$ \\
\hline \multirow{2}{*}{ Gender } & Male & 221 & 52.1 \\
\hline & Female & 203 & 47.9 \\
\hline \multirow{5}{*}{ Age } & $<20$ & 36 & 8.5 \\
\hline & $20-30$ & 78 & 18.4 \\
\hline & $30-40$ & 103 & 24.3 \\
\hline & $40-50$ & 115 & 27.1 \\
\hline & $>50$ & 92 & 21.7 \\
\hline \multirow{4}{*}{ Education } & High School & 42 & 9.9 \\
\hline & Junior college & 102 & 24.1 \\
\hline & Undergraduate & 219 & 51.6 \\
\hline & $\begin{array}{c}\text { Graduate and } \\
\text { above }\end{array}$ & 61 & 14.4 \\
\hline \multirow{5}{*}{ Occupation } & Bank Clerk & 45 & 10.6 \\
\hline & $\begin{array}{l}\text { Enterprise } \\
\text { Employee }\end{array}$ & 134 & 31.7 \\
\hline & Civil Servant & 32 & 7.5 \\
\hline & $\begin{array}{l}\text { Institution } \\
\text { Employee }\end{array}$ & 127 & 29.9 \\
\hline & Others & 86 & 20.3 \\
\hline \multirow{5}{*}{$\begin{array}{l}\text { Monthly } \\
\text { income }\end{array}$} & $<2000$ & 35 & 8.3 \\
\hline & $2000-4000$ & 53 & 12.5 \\
\hline & $4000-6000$ & 121 & 28.5 \\
\hline & $6000-8000$ & 128 & 30.2 \\
\hline & $>8000$ & 87 & 20.5 \\
\hline
\end{tabular}

Table 1. Sample feature distribution table

\subsection{The Design of Questionnaire}

The questionnaire consists of two parts: the first part is the demographic characteristics; the second part of the survey is the measured value of structure variables in the studying model. The questionnaire was distributed to experts in two mobile banking banks and two professors of financial research at universities to review and revise according to their opinions in China. Table 2 is the main content of the questionnaire.

\subsection{Data Analysis}

Table 2 lists the distribution of the sample the following year, the main test of people's sex, age, education, occupation, and income and as such having impacts on trust, and the test of factors of Table 1 in the mobile communication technology platform, mobile financial trading platform, and smart phones and as such having impacts on the trust.

From the 424 questionnaires collected, we can see that men have better sense of experiences than women in the use of mobile banking for mobile financial transactions, and can feel that mobile banking brings fast, convenience, and safe in a better way. In terms of 
Table 2. Part of the questionnaire.

\begin{tabular}{|c|c|c|c|c|c|}
\hline \begin{tabular}{|c|} 
Measurement \\
Factors \\
\end{tabular} & \begin{tabular}{|c|} 
Measured \\
Values \\
\end{tabular} & Main Content & $\begin{array}{c}\text { Measurement } \\
\text { Factors }\end{array}$ & $\begin{array}{c}\text { Measured } \\
\text { Values } \\
\end{array}$ & Main Content \\
\hline \multirow{7}{*}{$\begin{array}{l}\text { Structure } \\
\text { Assurance }\end{array}$} & \multirow[b]{2}{*}{1} & \multirow{2}{*}{$\begin{array}{l}\text { Mobile banking financial trading } \\
\text { system provides adequate technical } \\
\text { assurance measures, allowing people } \\
\text { to feel very comfortable in the } \\
\text { process of financial transactions }\end{array}$} & \multirow{3}{*}{$\begin{array}{l}\text { Perceived } \\
\text { Satisfaction }\end{array}$} & 1 & $\begin{array}{l}\text { The bank's reputation in mobile } \\
\text { banking is very good }\end{array}$ \\
\hline & & & & 2 & $\begin{array}{l}\text { The bank of the mobile banking } \\
\text { provides a good service }\end{array}$ \\
\hline & 2 & $\begin{array}{l}\text { I think that telecom operators, } \\
\text { mobile banking take measures to } \\
\text { fully guarantee the use of mobile } \\
\text { banking without technical problems } \\
\end{array}$ & & 3 & $\begin{array}{l}4 \mathrm{G} \text { communication quality is } \\
\text { very good, and mobile banking } \\
\text { also provides good service }\end{array}$ \\
\hline & \multirow{2}{*}{3} & \multirow{2}{*}{$\begin{array}{l}\text { I believe that } 4 \mathrm{G} \text { communication } \\
\text { technology, mobile banking } \\
\text { authentication, data security and } \\
\text { other technologies can guarantee } \\
\text { security and reliability of mobile } \\
\text { banking financial trading system }\end{array}$} & \multirow{2}{*}{$\begin{array}{l}\text { Perceived Ease } \\
\quad \text { of Use }\end{array}$} & 1 & $\begin{array}{l}\text { Mobile banking can provide a } \\
\text { convenient mobile financial } \\
\text { operation interface }\end{array}$ \\
\hline & & & & 2 & $\begin{array}{l}\text { Mobile banking can provide } \\
\text { convenient mobile phone safety } \\
\text { certifications for users }\end{array}$ \\
\hline & \multirow[t]{2}{*}{4} & \multirow{2}{*}{$\begin{array}{l}\text { I believe that } 4 \mathrm{G} \text { communication } \\
\text { technology, mobile banking } \\
\text { certification, data security and } \\
\text { mobile banking financial } \\
\text { transactions have legal guarantee } \\
\text { mechanism }\end{array}$} & \multirow{3}{*}{ Initial Trust } & 1 & $\begin{array}{l}\text { Mobile banking has always been } \\
\text { able to provide accurate and } \\
\text { convenient financial transaction } \\
\text { services }\end{array}$ \\
\hline & & & & 2 & $\begin{array}{l}\text { Mobile banking can provide } \\
\text { secure and reliable financial } \\
\text { transaction services }\end{array}$ \\
\hline \multirow[b]{2}{*}{ Ubiquity } & 1 & $\begin{array}{l}\text { Use of mobile banking can carry out } \\
\text { financial transactions at any time, } \\
\text { without time constraints }\end{array}$ & & 3 & $\begin{array}{l}\text { Mobile banking has been able to } \\
\text { provide safe, reliable, and fast } \\
\text { financial transaction services }\end{array}$ \\
\hline & 2 & $\begin{array}{l}\text { Use of mobile banking can carry out } \\
\text { financial transactions anywhere, } \\
\text { regardless of time or geographical } \\
\text { restrictions }\end{array}$ & $\begin{array}{l}\text { Experience } \\
\text { Sense }\end{array}$ & 1 & $\begin{array}{l}\text { I plan to open mobile banking } \\
\text { services }\end{array}$ \\
\hline \multirow{3}{*}{$\begin{array}{l}\text { Information } \\
\text { Quality }\end{array}$} & 1 & $\begin{array}{l}\text { Mobile banking can provide a } \\
\text { secure, stable financial transaction } \\
\text { information platform }\end{array}$ & \multirow[t]{2}{*}{ Trust Trend } & 1 & $\begin{array}{l}\text { I have opened mobile banking } \\
\text { financial services }\end{array}$ \\
\hline & 2 & $\begin{array}{l}\text { Mobile banking can provide timely } \\
\text { financial transaction information }\end{array}$ & & 2 & $\begin{array}{l}\text { I am ready to launch mobile } \\
\text { banking services }\end{array}$ \\
\hline & 3 & $\begin{array}{l}\text { Mobile banking can provide reliable } \\
\text { users' authentications, data security, } \\
\text { and timely financial transaction } \\
\text { information }\end{array}$ & & & \\
\hline
\end{tabular}

age, because young people accept new technology very quickly and can experience mobile banking mobile banking financial transactions in a better way than older people do, the proportion of its use of mobile banking decreases as age increases. Then speaking to the level of education, people with higher degrees of education have higher awareness of new technologies and the stronger the sense of experience than those with lower ones. In addition, from the perspectives of occupations, the results of use of mobile banking comparison are: corporate employee is of the highest, and then followed by others, institution employee, bank clerk, and civil servant. Last but not least, in views of wage income, impacts of wage income on use of mobile banking experience are not as obvious as what have discussed above. 
In order to test the influence of various factors on the tendency of trust and the moderating effect, we use structural equation model to analyze the adjustment of each factor and trust tendency. Besides having direct effects on the initial trust of the mobile phone banks, mobile banking users' trust tendencies also play an important regulatory role on other factors such as structure assurance, ubiquity, information quality, initial trust, perceived ease of use, and so on.

Fig. 2 shows the relationship between trust tendency and structural assurance. As can be seen from the figure, structural assurance measures can be more perfect with better trust tendency.

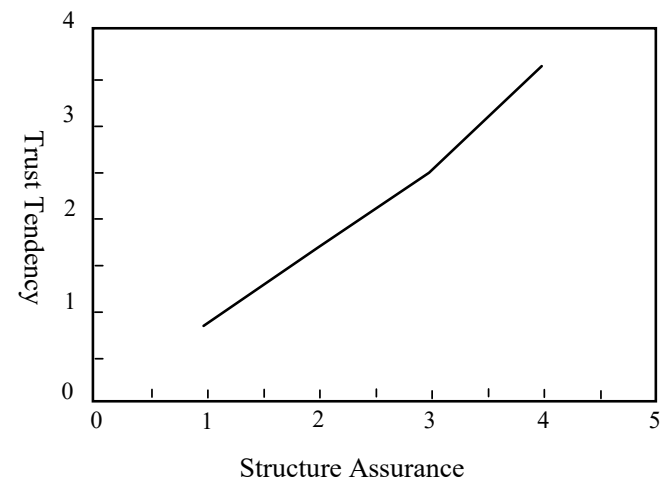

Fig. 2. The relationship between trust orientation and structural assurance.

Fig. 3 shows the relationship between trust tendency and ubiquitous regulation, which can be seen from the figure that trust tendency are better with wider coverage area of $4 \mathrm{G}$ mobile communication under no restrictions of time for mobile payment.

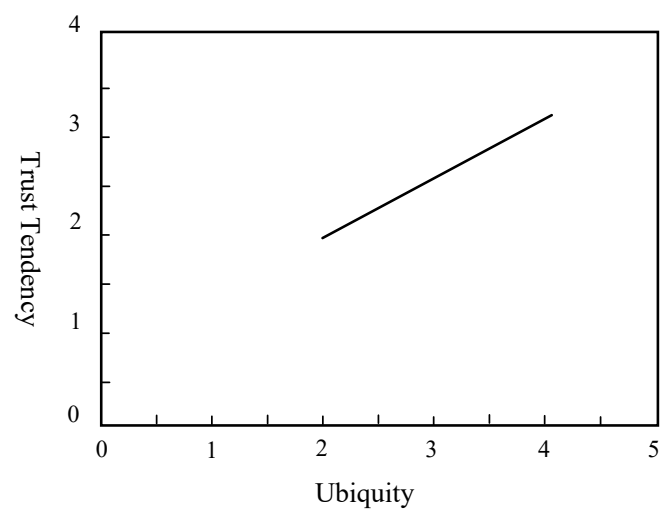

Fig. 3. Regulatory relationship between trust tendency and ubiquity.
Fig. 4 shows the relationship between trust tendency and information quality. It can be seen from the figure that the data transmission of $4 \mathrm{G}$ mobile communication technology fast, reliability, and data security plays an important role in trust tendency.

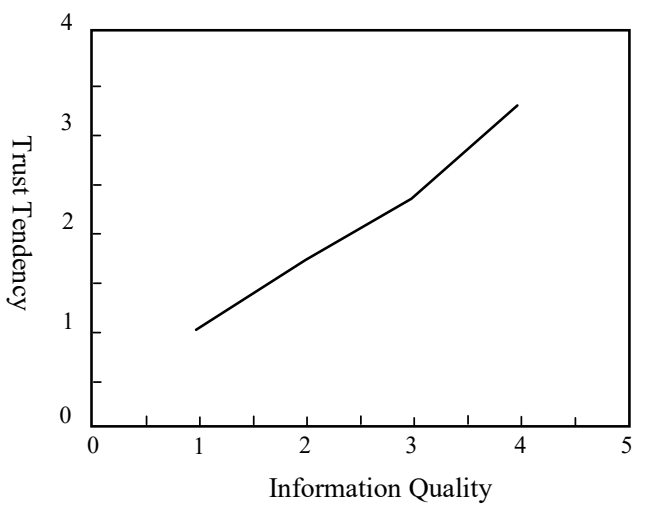

Fig. 4. The relationship between trust tendency and information quality.

Fig. 5 shows that the initial trust of mobile banking has a good perceptual effect on trust tendency, showing that it is very important for mobile banking to provide safe, reliable, and fast financial payment service.

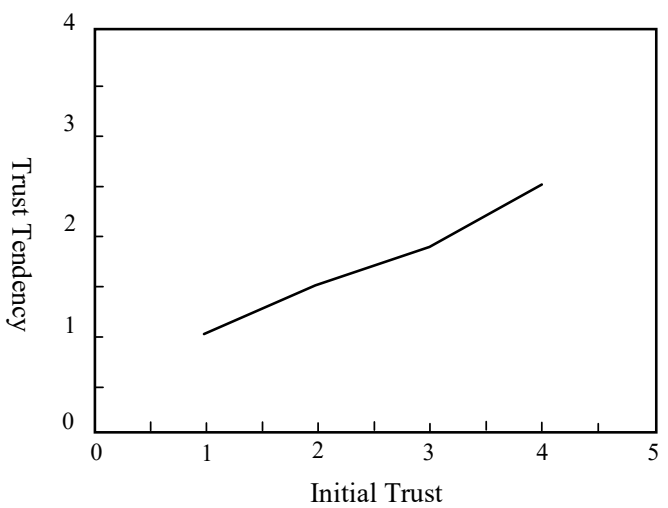

Fig. 5. Relationship between trust tendency and initial trust.

Fig. 6 shows that perceived satisfaction has a trust relationship with the trust tendency, which shows that service quality of mobile banking and of mobile telecom operators has a significant effect on user satisfaction.

Fig. 7 is the relationship between trust and the number of mobile banking payments, which can be seen from the figure, the more the number of trust payments, the higher the trust, indicating that their mobile financial payment security and reliability are better. 


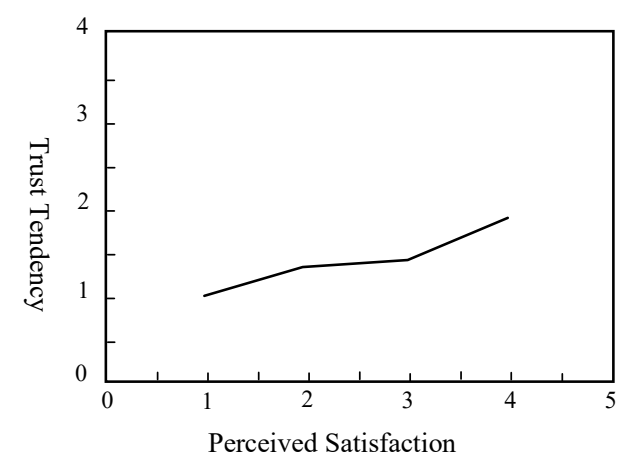

Fig. 6. The relationship between trust inclination and perceived satisfaction.

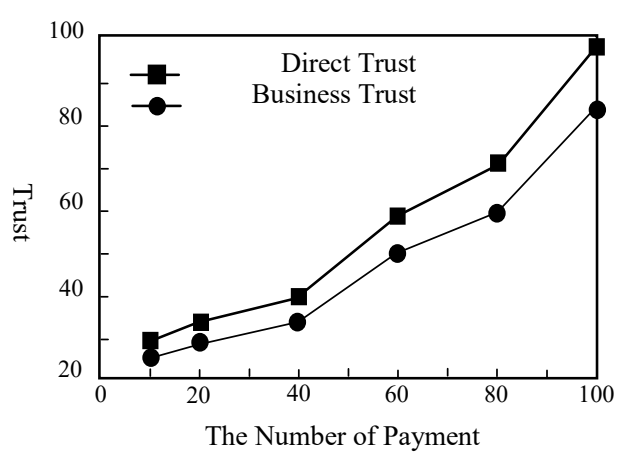

Fig. 7. The relationship between trust and the number of payment.

\section{Conclusion and Discussion}

This article studies several important factors that affect initial trust in mobile banking. According to the results of questionnaire survey and previous data analysis, there are some important conclusions which are: (1) structure of quality assurance and information are the most important factors that affect the emergence of initial trust in mobile banking, showing that mobile banking users will take a fancy to the architecture of mobile banking, trading platform, the service quality of mobile communication operators, and the security of financial transactions; (2) the ubiquity embodies the advantages of mobile financial transactions, and directly influences the mobile banking users of mobile operators, mobile banking confidence, and experience. Ubiquity is able to pay for mobile banking users to provide timely financial activities, for example, when business trip or travel, mobile banking users can pay by mobile banking activities and query account information; (3) the structure of guarantee is the most significant factor that influences the mobile banking initial trust. When the mobile banking and mobile banking users are not in interaction, users will pay special attention to the security of mobile banking payment environment, the reliability of the data. Therefore, mobile banking and mobile communication operators should provide adequate security and protection measures to reduce the risk of mobile banking users attention; (4) mobile banking users trust tendency not only has important and direct influence on the initial trust, but also adjust the influence of other factors, including the structure quality, perceived ease of use, and information on the influence of initial trust; (5) the effects of sense of satisfaction on initial trust of mobile banking users are not pronounced. A reasonable explanation may be that domestic mobile communication operators and the support of mobile phone bank scale are relatively large, then their reputation are better in return; (6) the quantity of users' payments has a direct and important influence on mobile banking trust, meaning that trust of mobile banking increases as the quantity of payment goes up, so plays an important role on use and promotion of mobile banking.

\section{Acknowledgements}

This article is supported by the National Social Science Foundation of China (No. 14BJY171), The National Natural Science Foundation of China (No. 61572012), The Key Natural Science Foundation of Hubei Province of China (No. 2014CFA055).

\section{References}

1. China Financial Certification Center. 2015 China ebanking survey. http://www.financialnews.com.cn/yw/jryw/201512/t2015 1207_88383.html, 2015-12-07.

2. Jun-feng Tian, and Hong-yun Cai. Relationship between trust model and its development. JOURNAL OF HEBEI UNIVERSITY (NATURAL SCIENCE EDITION), 2011, 31(5): 555-560.

3. A. A. Shaikh, H. Karjaluoto. Mobile banking adoption: A literature review. Telematics and Informatics, 2015, 32(1): 129-142

4. Ze-nan Fang, Wei-gang Liu, and Guang-zhuo Yu. Study on the security of mobile banking. Microcomputer and Applications, 2013, 32 (24): 4-6.

5. David Carfi and Francesco Musolino. A Coopetitive Approach to Financial Markets Stabilization and Risk Management. Communications in Computer and Information Science, 2012, 300(4): 578-592. 
6. S. Afshan, A. Sharif. Acceptance of mobile banking framework in Pakistan. Telematics and Informatics, 2016, 33(2): 370-387.

7. Jiabao Lin and Yaobin Lu. Study on initial trust model of mobile securities users. Management Review, 2011, 23 (11): 59-68.

8. Hsiu-Fen Lin. An empirical investigation of mobile banking adoption: the effect of innovation attributes and knowledge-based trust. International Journal of Information Management, 2011, 31(3): 252-260.
9. Shuihong Yao and Zhenzhen Chen. The impact of mobile banking service quality on continuous trust. Economy and Management, 2013, 27 (11): 78-82.

10. Tao Zhou. Examining mobile banking user adoption from the perspectives of trust and flow experience. Information Technology and Management, 2012, 13(1): 13:27-37.

11. Baolin Sun, Chao Gui, Chang Liu, Xuan-yu Chen, and Chaohao Sun. Multi-dimensional trust evaluation of mobile banking risk index system. 